ISSN: 2302-8556

E-Jurnal Akuntansi Universitas Udayana

Vol.24.3.September (2018):2197-2225

DOI: https://doi.org/10.24843/EJA.2018.v24.i03.p21

\title{
Pengaruh Idealisme, Relativisme Dan Etika Pada Persepsi Mahasiswa Akuntansi Atas Perilaku Etis Akuntan
}

\author{
Ni Made Hanny Ariyanti ${ }^{1}$ \\ A. A. G. P. Widanaputra ${ }^{2}$ \\ ${ }^{1}$ Fakultas Ekonomi dan Bisnis Universitas Udayana (Unud), Bali, Indonesia \\ email: hannyariyanti70@gmail.com/ Telp : 082144336727 \\ ${ }^{2}$ Fakultas Ekonomi dan Bisnis Universitas Udayana (Unud), Bali, Indonesia
}

\begin{abstract}
ABSTRAK
Dalam penelitian ini perilaku etis akuntan dipengaruhi oleh idealisme, relativisme, dan etika. Perilaku etis merupakan perilaku seseorang bertindak sesuai dengan hukum, peraturan, dan moral Penelitian ini untuk menguji pengaruh etika pada persepsi mahasiswa non regular jurusan akuntansi Fakultas ekonomi dan Bisnis Universitas Udayana atas perilaku etis akuntan. Penelitian berikut memakai data primer yang dikumpulkan dengan memakai kuesioner sebagai instrument pengumpulan data yang disebarkan ke responden. Responden penelitian berikut yaitu mahasiswa non reguler jurusan akuntansi angkatan 2014 Fakultas Ekonomi dan Bisnis Universitas Udayana. Banyaknya sampel yang didapatkan yaitu 127 sampel dan penentuan sampel menggunakan metode non probability sampling dengan teknik purposive sampling. Teknik analisis data yang digunakan adalah analisis regresi linear berganda. Berdasarkan hasil analisis menunjukan bahwa idealisme berpengaruh positif pada persepsi mahasiswa akuntansi atas perilaku etis akuntan, relativisme berpengaruh negatif pada persepsi mahasiswa akuntansi atas perilaku etis akuntan dan etika berpengaruh positif pada persepsi mahasiswa akuntansi atas perilaku etis akuntan.
\end{abstract}

Kata kunci: idealisme, relativisme, etika dan perilaku etis akuntan

\begin{abstract}
This reseacrh about ethical behavior of accountants is influenced by idealism, relativism, and ethics. Ethical behavior is the behavior of a person acting in accordance by laws, regulations, and morals. This reseacrh examine influence of ethics to perception of nonregular students majoring in accounting Faculty of Economics and Business Udayana University by ethical behavior of accountants. This research used primary data collected by using questionnaires as instrument of data collection distributed to respondents. Respondents of this research are 127 student as sampel by non-probality sampling method of non-regular students majoring in accounting class of 2014 Faculty of Economics and Business Udayana University. The results by using multiple linier regression is idealism positively affect the perception of accounting students, relativism negatively affect the perception of accounting students for ethical behavior of accountants and ethics have a positive effect on the perception of accounting students for ethical behavior of accountants Keywords: idealism, relativism, ethics and ethical conduct of accountants
\end{abstract}


Ni Made Hanny Ariyanti dan A. A. G. P. Widanaputra. Pengaruh...

\section{PENDAHULUAN}

Prilaku etis merupakan prilaku seorang yang bersikap menuruti hukum, peraturan, serta moral yang sudah diterapkan. Prilaku etis sangatlah penting agar dipraktekkan untuk seluruh bidang profesi, tapi di dunia nyata masihlah sering terjadinya sebuah pelanggaran etika sehingga bisa menimbulkan skandal-skandal pada profesi itu. Begitu banyaknya pihak yang dapat kena dampak daripada skandal yang terjadi didalam bidangnya, baik untuk yang telah berkecimpung di dalamnya ataupun mereka yang telah siap-siap diri agar masuk ke sebuah profesi itu. Sugiantari (2016) memberi pernyataan bahwasannya meskipun seluruh profesi, termasuk profesi akuntansi mempunyai etika profesi tetapi etika itu dibentuk berdasarkan rasionalisme ekonomi saja, jadi wajar etika itu tak sanggup membuat manusia terhindar daripada hukuman moral serta etika agar berfokus pada keuntungan material. Bidang profesi akuntansi pun tidak luput dari pelanggaran dan kecurangan yang menimbulkan krisis etika dan menyebabkan profesionalisme dan perilaku etis akuntan menjadi krisis kepercayaan. Krisis kepercayaan ini diketahui dengan maraknya kasus pelanggaran etika yang melibatkan para akuntan.

Kasus skandal akuntansi yang paling banyak diketahui adalah skandal Enron dan KAP Arthur Anderson. Enron Corp., adalah satu dari sekian organisasi energy distribution paling besar di AS. Enron bekerja sama dengan KAP Arthur Anderson memalsukan laporan keuangan yang terdapat selama sekian tahun sehingga membuat saham Enron jadi lebih meninggi. Skandal Enron tersebut seharusnya tidak terjadi jika setiap akuntan memiliki pemahaman dan menetapkan 
etika secara memadai dalam pelaksanaan pekerjaan profesionalnya (Mella, 2015). Selain skandal Enron dan KAP Arthur Anderson, saat ini di Indonesia juga terungkap kasus yang melibatkan auditor BPK yang dilakukan oleh Wulung dalam kasus e-KTP yang ditaksir merugikan Negara mencapai 2,3 triliun rupiah. Wulung selaku auditor pada BPK yang memeriksa keuangan Ditjen Dukcapil menerima sejumlah Rp. 80 juta rupiah pada tahun 2010 kemudian memberikan opini wajar tanpa pengeculian (WTP) (news.liputan6.com).

Berdasarkan kasus-kasus pelanggaran etik tanpa disadari membentuk suatu reaksi yang menjadi sebuah persepsi dari mahasiswa pada profesi di bidang akuntansi. Persepsi adalah sikap ataupun pendapat yang dicurahkan untuk memberi respon ataupun memberi tafsiran suatu fenomena. Dalam penelitian ini bertujuan untuk mengetahui bagaimana persepsi mahasiswa atas prilaku etis akuntan dan setiap mahasiswa harus memiliki persepsi moral, penalaran serta prilaku yang berbeda-beda, biarpun mereka sudah mengenyam pendidikan etika dengan porsi yang merata (Smith, 2009). Berdasar penjelasan tersebut, maka sangat memiliki alasan bila pendidikan tinggi akuntansi memberi respon dengan usaha untuk masuk ataupun integrasi etika pada kurikulum. Di Indonesia, adanya mata kuliah yang berisi muatan etika tidaklah lepas daripada misi yang dibawa oleh pendidikan tinggi akuntansi untuk menjadi subsistem pendidikan tinggi, yang bukan saja bertanggungjawab mendidik mahasiswa supaya memiliki kepribadian (personality) yang utuh sebagai manusia (Ludigdo dan Machfoedz, 1999).

Dunia pendidikan akuntansi sangat memegang andil yang vital untuk membentuk akuntan yang profesional serta memiliki prilaku etis. Mahasiswa 
akuntansi yang kedepan dapat menjadi calon akuntan harus mempelajari juga harus paham problem dari etika, untuk hal berikut etika profesi akuntan yang nanti akan mereka jalanipada dunia pekerjaan. Dunia pendidikan yang baik akan membentuk mahasiswa jadi calon akuntan yang memiliki sifat profesional yang berdasarkan kepada standar moral serta etika, jadi nanti tidaklah kejadian lagi kasus-kasus skandal seperti yang sudah pernah terjadi.

Di Indonesia isu tentang etika serta pelanggaran etis yang dilaksanakan para profesional telah sangat lama dijadikan perhatian yang sangat serius. Seorang akuntan saat melakukan profesinya untuk memriksa telah diberi aturan sesuai Kode Etik Ikatan Indonesia (Revita, 2014). Tetapi, masihlah dilihat mahasiswa yang tidak tahu tentang adanya skandal ini di Indonesia. Banyak mahasiswa yang belum terlalu memikirkan masalah-masalah dunia kerja yang mana mereka belum pernah melakoninya. Para mahasiswa biasanya lebih asik dengan dunianya sendiri dan sering mengacuhkan hal-hal yang terjadi meskipun mereka mengetahuinya, karena hal tersebut tidak berkaitan dengan dirinya ( Ferdinandus, 2016). Hal ini akan menimbulkan rasa khawatir karena mahasiswa tidak peka terhadap masalahmasalah yang terjadi khususnya yang mencakup etika profesi yang nantinya mereka akan sulit beradaptasi jika mereka dihadapkan oleh situasi yang sama. Selain itu, naiknya prilaku tidak etis disebabkan dikarenakan tidak adanya perhatian pada etika didalam pendidikan ataupun praktek yang telah mahasiswa terima di kala ini. Oleh sebab itu dapat sangatlah menarik untuk bisa tahu bagaimanakah reaksi yang diberikan oleh mahasiswa akuntansi tentang penting atau tidaknya memiliki prilaku etis yang melibatkan profesi akuntan. 
Penelitian ini menganalisis mengenai pengaruh idealisme, relativisme, dan etika pada persepsi mahasiswa akuntansi atas perilaku etis akuntan. Penelitian ini penting dilakukan karena banyak fakta perilaku akuntan yang melanggar kode etik atau etika profesi akuntan, padahal sangat disarankan bagi semua profesi untuk berperilaku etis sesuai dengan nilai-nilai moral yang berlaku (Damayanthi, 2016). Penelitian mengenai etika sudah banyak dilakukan tetapi pelanggaran etika masih tetap terjadi. Hal ini menyebabkan krisis kepercayaan masyarakat terhadap profesi akuntansi dan penelitian ini dilakukan untuk mendeteksi apakah faktor idealisme, relativisme, dan etika mampu mempengaruhi perilaku etis seseorang, terutama terhadap persepsi para mahasiswa akuntansi sebagai calon akuntan profesional.

Idealisme adalah sikap prilaku seorang agar tak membuat pelanggaran pada nilai-nilai etika yang dapat membuat kerugian pada orang lain. Seseorang yang idealis yang tinggi memiliki prinsip bahwasanya membuat individu lain merugi merupakan hal yang selalu bisa ataupun haruslah mereka hindari serta mereka tak bisa melaksanakan tindakan yang memiliki arah pada sika yang memiliki konsekuensi negatif. Disamping hal tersebut, seseorang yang idealis akanlah selalu berpegang teguh pada prilaku etis didalam profesi yang mereka jalani. Namun, seseorang yang sikap idealismenya lebih rendah, dapat mempunyai anggapan bahwasannya dengan mereka ikut seluruh prinsip moral yang ada bisa mengakibatkan hal negatif. Seseorang dengan idealisme yang rendah akan memiliki pendapat bahwasannya kadang diperlukan sedikit prilaku negatif agar memperoleh hasil yang paling baik (Forsyth,1992). 
Penelitian yang dilakukan oleh Milyawati, dkk (2017) menunjukkan bahwa tingkat idealisme berpengaruh pada opini mahasiswa terhadap perilaku etis akuntan. Hasil penelitian tersebut juga didukung oleh Setiawan (2013) dan Putra (2015) memberi petunjuk bahwasannya idealisme memiliki pengaruh signifikan positif pada perilaku etis. Ini berarti bahwa hubungan idealisme searah dengan perilaku etis akuntan. Dapat diartikan semakin tinggi tingkat idealisme yang dimiliki seseorang maka akan meningkatkan perilaku etisnya dalam melaksanakan tanggungjawab sebagai profesional akuntansi. Hal ini juga membuktikan bahwa seseorang memiliki idealisme tinggi dalam memegang prinsip etika maka seseorang akan senantiasa berperilaku etis. Idealisme dalam memegang prinsip etika tentunya tidak timbul dengan sendirinya. Kebiasaan untuk berperilaku etis adalah faktor penting untuk membangun idealisme dalam berorientasi dan didukung dengan teori moral kognitif yang menyatakan pada tingkat conventional tahap ketiga, dimana tahap ketiga memiliki orientasi terhadap kesesuaian interpersonal. Prilaku yang baik di tahap berikut merupakan memenuhi ekspetasi serta merasakan loyalitas dan mendapat kepercayaan dari lingkungannya. Berdasar uraian itu, jadi peneliti bisa membuat rumusan hipotesis sebagai berikut $\mathrm{H}_{1}$ : Semakin tinggi sifat idealis seorang mahasiswa maka semakin tinggi persepsi mahasiswa akuntansi atas perilaku etis akuntan.

Relativisme merupakan teori dapat memberi pernyataan bahwasannya sebuah prilaku bisa dibilang etis ataupun tidak etis memiliki ketergantungan pada pandangan dari masyarakat (Forsyth, 1992). Relativisme merupakan model cara mempunyai pikiran pragmatis, alasannya yaitu bahwasannya aturan etika mempunyai sifat tak universal dikarenakan latar belakang etika adalah budaya 
dimana masing-masing budaya mempunyai aturan yang tidak sama. Seseorang dengan relativisme yang tinggi justru tidaklah menghiraukan prinsip-prinsip yang ada serta lebih beradaptasi dengan kondisi lingkungan sekitar sebelum akhirnya melakukan tindakan ataupun memberi respon sebuah kejadian yang melakukan pelanggaran etika.

Penelitian yang dilakukan oleh Nurfarida (2011), Setiawan (2013), dan Putra (2015) menunjukkan bahwa relativisme berpengaruh signifikan terhadap perilaku etis. Ini berarti bahwa hubungan relativisme berlawanan arah dengan perilaku etis akuntan. Dapat diartikan semakin tinggi tingkat relativisme seseorang maka akan menurunkan perilaku etis dalam melaksanakan tanggung jawab sebagai profesional akuntansi. Hal ini dikarenakan seseorang tidak cukup dominan dalam mengarahkan kecenderungan orientasi etikanya ke orientasi relativisme, serta dalam teori moral kognitif yang dinyatakan pada tingkat preconventional tahap kedua yang memiliki orientasi terhadap instrumen serta relativitas, dimana di tahapan berikut tindakan yang betul yaitu yang bisa mempunyai fungsi untuk instrument agar memberi kepuasan kebutuhan anak itu sendiri ataupun kebutuhan mereka yang peduli pada anak tersebut. Dapat dikatakan bahwa seseorang dalam satu sisi mereka menyikapi suatu tindakan etis adalah didasarkan pada situasi yang relative, namun bagi mereka sudah terbiasa untuk berperilaku etis dalam situasi ini perilaku relative tidak dapat berjalan dengan absolut. Berdasarkan uraian tersebut, maka peneliti merumuskan hipotesis sebagai berikut:

$\mathrm{H}_{2}$ : Semakin tinggi sifat relativisme seorang mahasiswa maka semakin rendah persepsi mahasiswa akuntansi atas perilaku etis akuntan. 
Etika adalah cara-cara untuk memiliki tingkah laku yang baik dari sudut pandang budaya, susila, ataupun agama. Etika adalah sebuah prinsip moral serta perbuatan yang dijadikan dasar tindakan seorang hingga apa yang dilaksanakannya diberi pandangan oleh masyarakat sebagai kegiatan terpuji serta dapat memberi peningkatan untuk martabat serta kehormatan seorang (Munawir, 2005). Sebagai seorang akuntan yang profesional harus menyadari adanya tanggung jawab kepada publik, klien, dan kepada sesama rekan praktisi, termasuk perilaku yang terhormat, bahkan jika hal tersebut berarti mengorbankan kepentingan pribadi (Arens, 2012:68).

Penelitian yang dilakukan oleh Dewi (2010) dan Pamela (2014) menunjukkan bahwa etika berpengaruh signifikan positif terhadap perilaku etis akuntan. Hal ini juga didukung dengan teori moral kognitif pada tingkat postconventional tingkat nomor lima yang memiliki orientasi terhadap kontrak sosial. Seorang jadi sadar bahwasannya memiliki hubungan beragam pandangan serta pendapat pribadi yang bertentangan serta lebih tertekan pada cara yang adil agar tercapainya consensus di sebuah kesalahpahaman, kontrak, serta proses matang. Dalam memberikan tanggapan mengenai prinsip etika profesi akuntan, mahasiswa yang memiliki etika tinggi akan lebih bersikap bijaksana dan memberikan tanggapan baik terhadap perilaku etis dibandingkan dengan mahasiswa yang memiliki etika rendah yang akan memberikan tanggapan bahwa bersikap melanggar etika adalah suatu sikap yang tidak merugikan. Berdasar uraian diatas, jadi peneliti dapat membuat rumusan hipotesis sebagai berikut:

$\mathrm{H}_{3}$ : Semakin tinggi etika seorang mahasiswa maka semakin tinggi persepsi mahasiswa atas perilaku etis akuntan. 


\section{METODE PENELITIAN}

Penelitian berikut memakai pendekatan kuantitatif dengan tingkat eksplansi penelitian memiliki bentuk asosiatif. Menurut Sugiyono (2017) metode penelitian kuantitatif disebut sebuah metode positivistik karena mempunyai landasan pada filsafat positivisme, serta data penelitian berupa angka dan analisis menggunakan statistik. Penelitian asosiatif merupakan penelitian yang bertujuan untuk mengetahui hubungan antara dua variabel atau lebih. Penelitian ini dilakukan di Fakultas Ekonomi dan Bisnis jurusan akuntansi angkatan 2014 Program S1 non reguler dengan menyebarkan kuisioner yang beralamat di jln. P.B. Sudirman Denpasar. Objek pada riset berikut yaitu persepsi mahasiswa semester akhir (semester 6 ke atas) jurusan akuntansi FEB Non Reguler Unud pada persepsi mahasiswa akuntansi yang dipengaruhi oleh faktor idealisme, relativisme dan etika. Variabel independen di riset berikut yaitu idealisme (X1), relativisme (X2), dan etika (X3). Variable dependen di riset berikut yaitu persepsi mahasiswa akuntansi atas perilaku etis akuntan (Y).

Idealisme yaitu sikap prilaku seorang agar tak melanggar norma-norma etika yang dapat membuat kerugian pada orang lain. Cara pengukurannya adalah dengan cara menjawab pertanyaan tentang orientasi etis idealisme yang tertera di kuesioner yang akan dibagikan. Adapun indikator untuk mengukur idealisme antara lain: 1) Orang harus yakin bahwa perbuatan yang mereka lakukan akan membahayakan orang lain, sekecil apapun bahaya itu. 2) Sekecil apapun resiko yang terjadi pada orang lain tidak boleh dibiarkan. 3) Walaupun ada manfaat yang menguntungkan, namun tidak sedikitpun bahaya terjadi pada orang lain. 4) 
Ni Made Hanny Ariyanti dan A. A. G. P. Widanaputra. Pengaruh...

Seseorang tidak boleh membahayakan orang lain baik dengan psikologis ataupun fisik. 5) Seseorang tak boleh melakukan tindakan yang dapat mencoreng kehormatan individu lain. 6) Jika suatu tindakan dapat membahayakan orang yang tidak bersalah, maka seharusnya tidak tindakan itu dilakukan. 7) Adalah tidak bermoral untuk mencari pembenaran suatu tindakan. 8) Pada setiap masyarakat kehormatan dan keselamatan orang harus menjadi perhatian paling penting. 9) Adalah tidak perlu untuk mengorbankan keselamatan orang demi kepentingan orang lain. 10) Tindakan bermoral adalah tindakan yang mendekati kesempurnaan.

Relativisme merupakan sikap penolakan terhadap prilaku-prilaku yang melanggar nilai moral. Cara pengukurannya adalah dengan cara menjawab pertanyaan tentang orientasi etis relativisme yang tertera di kuesioner yang akan dibagikan. Adapun indikator untuk mengukur relativisme adalah sebagai berikut: 1) Tidak ada satu etika yang harus dimasukkan menjadi bagian kode etik manapun. 2) Prinsip etika bisa berubah dari situasi ke situasi lainnya. 3) Standar moral harus dianggap sebagai sesuatu yang bersifat individu. 4) Kita tidak bisa menilai kebenaran moralitas yang berbeda. 5) Keputusan apakah sesuatu itu etis atau tidak etis. 6) Standar moral adalah aturan pribadi yang sederhana. 7) Pertimbangan etis dalam hubungan antar pribadi sangat kompleks. 8) Menganut suatu aturan etika yang kaku dalam melakukan suatu tindakan. 9) Tidak ada aturan tentang berdusta, dusta diperbolehkan atau tidak tergantung pada situasi yang dihadapi. 10) Apakah dusta dianggap bermoral atau tidak bermoral. 
Etika meliputi suatu proses penentuan yang kompleks tentang apa yang harus dilakukan seseorang dalam situasi tertentu yang disifati oleh kombinasi dari pengalaman dan pembelajaran masing-masing individu. Cara pengukurannya adalah dengan cara menjawab pertanyaan tentang etika yang tertera di kuesioner yang akan dibagikan. Penilaian etika pada persepsi mahasiswa mengenai perilaku etis akuntan berkaitan dengan etika profesi akuntan yang terdiri dari: 1) Tanggung jawab profesi, 2) Kepentingan publik, 3) Integritas, 4) Objektifitas, 5) Kompetensi dan kehati-hatian, 6) Kerahasiaan, 7) Perilaku profesional, 8) Standar teknis.

Persepsi dapat dikatakan sebagai cara pandang seseorang dalam melihat suatu masalah atau permasalahan. Perilaku etis adalah prilaku yang cocok dengan nilai-nilai yang mereka terima secara umum yang memiliki hubungan dengan sikap-sikap yang benar serta baik. Prilaku etis bisa memberi ketentuan kualitas individu yang diberikan pengaruh oleh faktor-faktor yang berasal dari luar lalu dijadikan prinsip yang harus mereka jalani kedalam bentuk prilaku. Prilaku etis mempunyai indikator, diantara lain: 1) Mendapat pemahaman serta mengenal prilaku cocok dengan kode etik, 2) Melaksanakan tindakan yang konsisten dengan nilai serta rasa yakin, 3) Melakukan tindakan berdasar kepada nilai walaupun sulit agar melaksanakan hal tersebut, 4) Melakukan tindakan berdasar kepada norma meskipun adanya risiko yang sangat tinggi.

Populasi dalam penelitian ini yaitu mahasiswa jurusan akuntansi FEB Unud Non Reguler angkatan 2014 yang memiliki jumlah 186 orang. Peneliti memilih mahasiswa akuntansi angkatan 2014 non reguler berjumlah 186 orang karena untuk mempermudah keakuratan dalam memperoleh data yang digunakan sebagai 
sampel. Metode penentuan sampel pada riset berikut menggunakan metode non probability sampling dengan teknik secara purposive sampling, yaitu teknik pengambilan sampel dengan kriteria tertentu, dimana anggota sampel yang dipilih dapat mewakili sifat-sifat populasi. Adapun kriteria sampel yang ditentukan dalam penelitian ini yaitu Mahasiswa jurusan akuntansi Fakultas Ekonomi dan Bisnis Univeristas Udayana Non Reguler angkatan 2014 yang sudah menyelesaikan mata kuliah Pengauditan I serta Pengauditan II. Berdasar pada perhitungan Slovin, jadi peneliti bisa menentukan jumlah minimal sampel yang bersal populasi adalah 127 mahasiswa.

Penelitian berikut data kuantitatif yang didapatkan dari data kualitatif yang dikuantitatifkan menggunakan bantuan Skala Likert yang memberi acuan pada pengukuran variable yang dipakai. Pada penelitian ini data kualitatif berupa daftar pertanyaan-pertanyaan yang terdapat dalam kuesioner. Sumber data pada penelitian ini adalah mahasiswa non reguler angkatan 2014 jurusan akuntansi Fakultas Ekonomi dan Bisnis Universitas Udayana. Data ini berupa kuesioner yang telah diisi oleh mahasiswa non reguler angkatan 2014 jurusan akuntansi FEB Unud yang sudah menjadi responden di riset berikut. Data sekunder adalah bukti, catatan ataupun laporan historis yang sudah disusun pada arsip (data dokumenter) yang sudah publikasi ataupun tak dipublikasi. Data penelitian ini didapatkan dengan memakai metode tinjauan kepustakaan (library research) serta melakukan akses pada website ataupun situs-situs. Peneliti mempunyai usaha melakukan kumpulan data yang akurat dengan memakai kuesioner. Data kuantitatif pada riset 
berikut yaitu banyaknya responden yang memberi jawaban kuesioner. Pada penelitian berikut peneliti memakai data primer.

Sebelum dilakukan teknik analisis terhadap data yang dikumpulkan terlebih dahulu dilakukan pengujian instrumen penelitian dalam hal ini adalah pengujian validitas dan reliabilitas lalu dilakukan uji asumsi klasik dan analisis statistic deskriptif. Statistik deskriptif merupakan statistik yang menggambarkan atau mendeskripsikan data menjadi sebuah informasi yang lebih mudah untuk dipahami. Analisis regresi linear berganda dilaksanakan agar dapat diketahui hubungan diantara lebih dari dua variable, dimana satu variable sebagai variable terikat serta variable-variable lainnya sebagai variable bebas. Pengujian hipotesis ini dilaksanakan dengan memakai alat statistik SPSS (statistical package for social science) dengan tingkat signifikasi 5\% $(\alpha=0,05)$. Untuk melakukan pengujian hipotesis berkembang sebuah persamaan agar memberi pernyataan pada hubungan diantara variable bebas, adalah Y (Persepsi Mahasiswa Akuntansi atas Perilaku Etis Akuntan) terhadap variable bebas, adalah X (Idealisme, Relativisme dan Etika). Tepat atau tidaknya dari fungsi regresi sampel untuk memberi taksiran nilai aktual kita ukur dari goodness of fit-nya (Ghozali, 2016:97). Secara statistik hal itu bisa dilihat dari nilai koefisien determinasi $\left(\mathrm{R}^{2}\right)$, nilai statistik F (uji kelayakan model), serta nilai statistik t (Uji Signifikansi parameter individual).

\section{HASIL DAN PEMBAHASAN}

Data dalam penelitian ini dikumpulkan melalui survei dengan menyebarkan kuisioner kepada mahasiswa akuntansi non regular angkatan 2014 di FEB 
Unud secara langsung kepada Individual yang bersangkutan. Jumlah sampel yang digunakan adalah 186 mahasiswa yang memenuhi kriteria penarikan sampel. Peneliti sudah melakukan penyebaran kuesioner sejumlah 127 eksemplar dengan tingkat pengembalian responden 100 persen serta tingkat pengembalian yang bisa dilakukan analisis sejumlah 100 persen dengan rincian sebagai berikut. Tabel 1 memberikan petunjuk bahwasannya banyaknya kuesioner yang telah dilakukan penyebaran pada responden sejumlah 127 kuesioner, yang kembali sejumlah 127 kuesioner serta telah diperiksa seluruh kuesioner cocok dipakai dalam proses analisa berikutnya.

\section{Tabel 1}

Rincian Pembagian Kuisioner

\begin{tabular}{lc}
\hline \multicolumn{1}{c}{ Uraian } & $\begin{array}{c}\text { Jumlah } \\
\text { Kuesioner }\end{array}$ \\
\hline Total Kuesioner yang disebar & 127 \\
Kuesioner dikembalikan & 127 \\
Kuesioner yang dibatalkan & 0 \\
Kuesioner yang digunakan dalam analisis & 127 \\
Tingkat pengembalian (response rate) $=127 / 127 \times 100 \%$ & $100 \%$ \\
Tingkat penggunaan (usable response rate) $=127 / 127 \times 100 \%$ & $100 \%$ \\
\hline
\end{tabular}

Sumber: Data Diolah, 2018

Karakteristik responden penelitian ini merupakan 127 responden yang berpartisipasi dalam pengisian kuesioner. Berdasarkan hasil penelitian yang dilaksanakan dapat dijelaskan gambaran mengenai responden berdasarkan jenis kelamin. Gender digunakan untuk mengetahui proporsi gender responden. Responden yang memiliki gender laki-laki berjumlah 44 orang (34,64 persen) dan responden yang memiliki gender perempuan berjumlah 83 orang $(65,35$ persen). Uji validasi untuk seluruh bulir dipakai analisis item, yang melakukan korelasi skor untuk seluruh bulir dengan skor total yang adalah banyaknya 
seluruh skor bulir. Semua variabel mempunyai besaran koefisien korelasi ada diatas 0,361 , jadi seluruh variabel tersebut layak untuk menjadi instrumen penelitian. Seluruh variable mempunyai besaran koefisien Alpha Cronbach ada diatas 0,60 jadinya seluruh instrument itu yaitu reliabel, jadi variable tersebut cocok untuk menjadi instrument penelitian.

Uji asumsi klasik yang dilaksanakan di riset berrikut ini termasuk uji normalitas, uji autokorelasi, uji multikolienaritas, serta uji heteroskedastisitas. Agar diketahui apakah data yang dipakai pada penelitian sudah berdistribusi normal bisa dilihat menggunakan uji non parametrik satu sampel KolmogorovSmirnov pada hasil uji regresi. Uji normalitas dengan memakai uji non parametrik satu sampel Kolmogorov-Smirnov memiliki tujuan agar memberi keyakinan apakah residual bisa berdistribusi dengan normal serta independen. Nilai Asymp. Sig (2-tailed) sejumlah 0,200. Dikarenakan Asymp. Sig (p-value) 0,200 lebih tinggi dari $\alpha(0,05)$ jadi bisa dibuat interprestasi bahwasannya residual dari model sudah terdistribusi normal. Pada riset berikut ini agar bisa dilakukan deteksi gejala multikolinieritas dilaksankan dengan melihat nilai Variance Inflation Factor (VIF). Multikolinearitas bisa kita lihat daripada nilai tolerance serta VIF (Varian Inflaction Factor), adalah jika besaran tolerance melebihi nilai 10 persen serta besaran VIF kurang daripada 10, ini memiliki arti tak ada multikolinearitas variable independen didalam model regresi berikut. Nilai tolerance variabel bebas tidak ada yang kurang dari 10 persen atau $(0,1)$ serta semua variable independen mempunyai besaran VIF kurang dari 10. Jadi bisa dibuat kesimpulan bahwasannya di data riset berikut, tak terjadinya 
multikolinearitas diantara variable independen pada model regresi berikut.

Model regresi yang bagus yaitu tak terjadi heteroskedastisitas. Pada riset berikut ini, agar bisa melakukan pendeteksian ada ataupun tidaknya heteroskedastisitas bisa dilaksanakan dengan melaksanakan Uji Glejser, adalah dengan melakukan regresi variable independen pada absolute residual. Bila variable dependen signifikan memberikan pengaruh variable independen, jadi terdapat indikasi terjadinya heterokedastisitas. Tidak adanya pengaruh variable independen $\left(\mathrm{X}_{1}, \mathrm{X}_{2}\right.$ dan $\left.\mathrm{X}_{3}\right)$ pada absolute residual (abs_res), baik secara serempak ataupun parsial dikarenakan nilai Sig. lebih tinggi daripada 0,05. Dengan demikian model yang dibuat tak mengandung gejala heteroskedastisitas, hingga layak dipakai untuk menganalisis.

Tabel 1.

Hasil Statistik Deskriptif

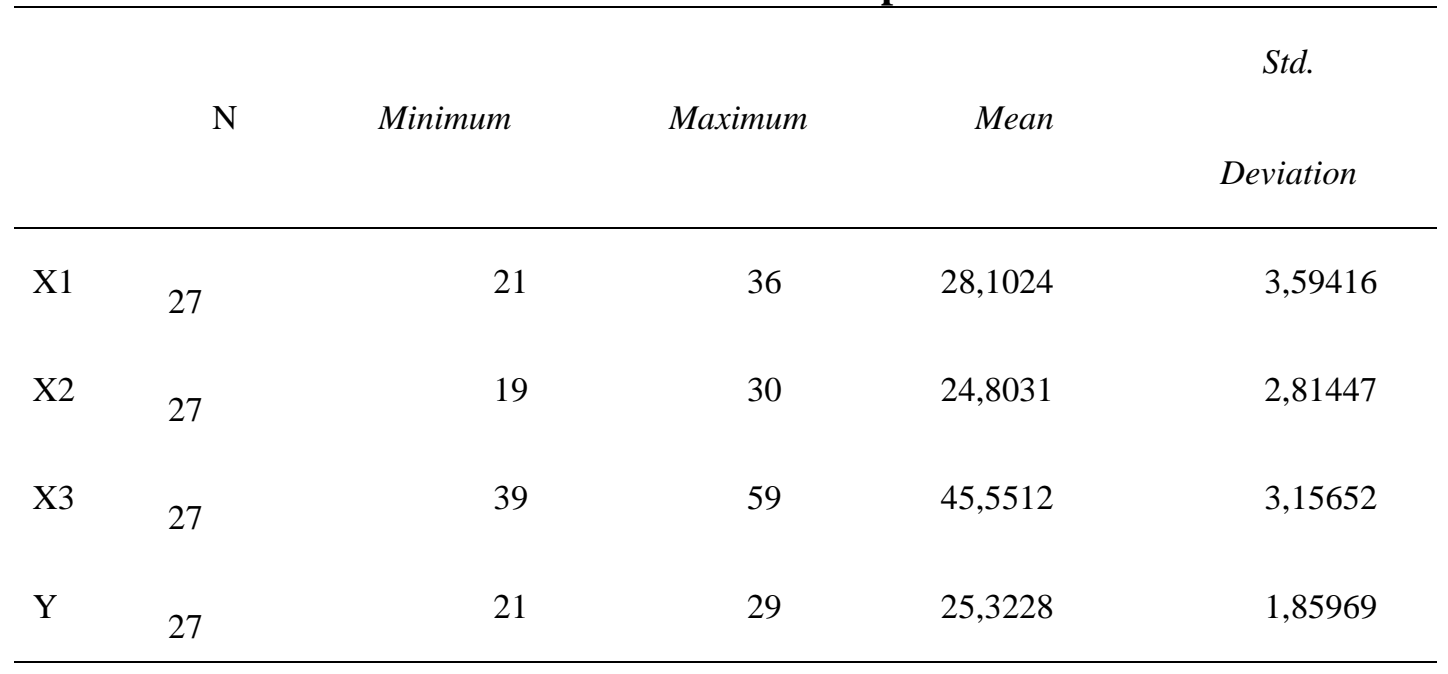

Sumber: Data Diolah, 2018

Statistik deskriptif dipakai agar membentuk gambaran daripada sebuah data yang kita lihat daripada jumlah sampel, nilai minimum, nilai maksimum, nilai rata-rata (mean), serta standar deviasi daripada tiap-tiap variable pada penelitian 
berikut. Berdasar kepada data olahan SPSS yang termasuk variabel idealisme, relativisme, etika serta persepsi mahasiswa akuntansi atas perilaku etis akuntan didapat hasil analisis data untuk statistik deskriptif yang dapat dilihat pada tabel 2 . Berdasar kepada hasil tabel 2 bahwasannya jumlah pengamatan $(\mathrm{N})$ di penelitian ini merupakan sejumlah 127 . Variabel idealisme $\left(\mathrm{X}_{1}\right)$ mempunyai nilai minimum sejumlah 21,00 serta nilai maksimum sejumlah 36,00 dengan nilai rata- rata sejumlah 28,1024. Deviasi standar pada variabel idealisme yaitu sejumlah 3,59416. Variabel relativisme $\left(X_{2}\right)$ mempunyai nilai minimum sejumlah 19,00 serta nilai maksimum sejumlah 30,00 dengan nilai rata-rata sejumlah 24,8031 . Standar devisiasi di variabel relativisme yaitu sejumlah 2,81447. Variabel etika $\left(\mathrm{X}_{3}\right)$ mempunyai nilai minimum sejumlah 39,00 serta nilai maksimum sejumlah 59,00 dengan nilai rata-rata sejumlah 45,5512. Standar devisiasi pada variabel etika yaitu sejumlah 3,15652. Variabel persepsi mahasiswa akuntansi atas perilaku etis akuntan (Y) mempunyai nilai minimum sejumlah 21,00 serta nilai maksimum sejumlah 29,00 dengan nilai rata-rata sejumlah 25,3228. Standar devisiasi pada variabel persepsi mahasiswa akuntansi atas perilaku etis akuntan yaitu sejumlah 1,85969 .

Pada penelitian ini, agar bisa melakukan analisis data dipakai metode analisis regresi berganda. Analisis regresi berganda dipakai agar mengetahui serta memberi petunjuk arah dan besar atau tidaknya pengaruh idealisme, relativisme juga etika baik dengan simultan ataupun parsial pada persepsi mahasiswa akuntansi atas perilaku etis akuntan. Dalam model analisis di riset berikut ini, yang dipakai menjadi variable independen yaitu idealisme $\left(\mathrm{X}_{1}\right)$, relativisme $\left(\mathrm{X}_{2}\right)$ 
serta etika $\left(\mathrm{X}_{3}\right)$. Lalu yang dipakai untuk variable dependen di riset berikut ini yaitu Persepsi mahasiswa akuntansi atas perilaku etis akuntan (Y). Analisis ini memakai bantuan Statistical Package For Social Science (SPSS) 21.0 dalam pengolahan.

Tabel 2.

Hasil Analisis Regresi Linear Berganda

\begin{tabular}{|c|c|c|c|c|c|}
\hline \multirow[t]{3}{*}{ Koefisien } & \multicolumn{2}{|c|}{$\begin{array}{l}\text { Unstandardized } \\
\text { Coefficients }\end{array}$} & \multirow{3}{*}{$\begin{array}{c}\begin{array}{c}\text { Standardized } \\
\text { Coefficient }\end{array} \\
\text { Beta }\end{array}$} & \multirow[t]{3}{*}{$\mathrm{t}$} & \multirow[t]{3}{*}{ Signifikansi } \\
\hline & \multirow[t]{2}{*}{ B } & Std. & & & \\
\hline & & Error & & & \\
\hline Konstanta (a) & 17,408 & 2,343 & & 7,43 & 0 \\
\hline Idealisme (x1) & 0,264 & 0,035 & 0,51 & 7,642 & 0 \\
\hline Relativisme (x2) & $-0,206$ & 0,044 & $-0,312$ & $-4,684$ & 0 \\
\hline Etika (x3) & 0,123 & 0,04 & 0,209 & 3,104 & 0,002 \\
\hline F hitung & & & & & 35,464 \\
\hline Signifikansi F & & & & & 0 \\
\hline R Square & & & & & 0,464 \\
\hline $\begin{array}{l}\text { Adjusted R } \\
\text { Square }\end{array}$ & & & & & 0,451 \\
\hline
\end{tabular}

Sumber: Data Diolah, 2018

Berdasar pada Tabel 3 memberikan petunjuk hasil analisis regresi linier berganda bisa diberi arti bahwasannya: 1) Hasil analisis kelayakan model $\mathrm{F}$ memberikan petunjuk bahwasannya nilai $\mathrm{F}$ hitung sejumlah 35,464 dengan besaran signifikansi uji $\mathrm{F}$ adalah sejumlah 0,000 lebih rendah daripada 0,05 yang memiliki arti $\mathrm{H}_{1}$ diterima serta $\mathrm{H}_{0}$ ditolak. Hasil berikut memberi makna bahwasannya variable idealisme, relativisme serta etika bisa ataupun cocok dipakai agar memberi prediksi variable persepsi mahasiswa akuntansi atas perilaku etis akuntan di FEB Unud. 2) Nilai t hitung pada variabel idealisme yaitu sejumlah 7,642 dengan tingkat signifikansi 0,000. Dengan memakai batas signifikansi 0,05 jadi signifikansi itu berada lebih kecil dari taraf 5 persen yang 
memiliki arti $\mathrm{H}_{0}$ ditolak serta $\mathrm{H}_{1}$ diterima. Hal ini memberi petunjuk bahwasannya idealisme memiliki pengaruh positif terhadap persepsi mahasiswa akuntansi atas perilaku etis akuntan. Koefisien regresi variabel idealisme $\left(\mathrm{X}_{1}\right)$ 0,264. Hal ini memiliki arti bahwasannya bila variable idealisme $\left(\mathrm{X}_{1}\right)$ meningkat satu satuan, jadi bisa menjadi akibat dalam meningkatnya pada persepsi mahasiswa akuntansi atas perilaku etis akuntan sejumlah 0,264, dengan asumsi variable independen lain dianggap konstan. 3) Nilai t hitung pada variabel relativisme yaitu sejumlah $-4,684$ dengan tingkat signifikansi 0,000. Dengan memakai batas signifikansi 0,05 jadi signifikansi itu berada lebih kecil daripada taraf 5 persen yang memiliki arti $\mathrm{H}_{0}$ ditolak serta $\mathrm{H}_{2}$ diterima. Hal ini memberi petunjuk bahwasanya relativisme memiliki pengaruh negatif terhadap persepsi mahasiswa akuntansi atas perilaku etis akuntan. Koefisien regresi variabel relativisme $\left(\mathrm{X}_{2}\right)-0,206$. Hal ini memiliki arti bahwasannya bila variable relativisme $\left(\mathrm{X}_{2}\right)$ meningkat satu satuan, maka akan memberikan akibat pada penurunan pada persepsi mahasiswa akuntansi atas perilaku etis akuntan sebesar 0,206, dengan asumsi variable independen lain dianggap konstan.

Nilai t hitung di variable etika yaitu sejumlah 3,104 dengan tingkatan signifikansi 0,002. Dengan memakai batas signifikansi 0,05 jadi signifikansi itu berada lebih kecil dari taraf 5 persen yang memiliki arti $\mathrm{H}_{0}$ ditolak serta $\mathrm{H}_{3}$ diterima. Hal ini memberi petunjuk bahwasannya etika memiliki pengaruh positif terhadap tingkat persepsi mahasiswa akuntansi atas perilaku etis akuntan. Koefisien regresi variabel etika $\left(\mathrm{X}_{3}\right)$ 0,123. Hal ini memiliki arti bahwasannya bila variable etika $\left(\mathrm{X}_{3}\right)$ meningkat satu satuan, maka dapat memberikan akibat 
pada peningkatan pada persepsi mahasiswa akuntansi atas perilaku etis akuntan sejumlah 0,123, dengan asumsi variable independen lain dianggap konstan. Koefisien determinasi $\left(\mathrm{R}^{2}\right)$ mempunyai tujuan agar mendapatkan ukuran berapa jauhnya kemampuan model untuk memberi keterangan variasi variable terikat. Besar nilai $R^{2}$ yaitu sejumlah 0,464 . Hal ini memiliki arti bahwasannya 46,4 persen variasi besarnya persepsi mahasiswa akuntansi atas perilaku etis akuntan b i s a diberikan penjelasan oleh idealisme, relativisme da etika. Sedangkan sisanya sebesar 53,6 persen dipengaruhi oleh variabel-variabel lain diluar model penelitian.

Hasil analisis menunjukan koefisien regresi idealisme memiliki tanda positif. Hal ini menunjukkan bahwa semakin tinggi sifat idealisme mahasiswa akuntansi menyebabkan persepsi mahasiswa akuntansi atas perilaku etis akuntan semakin tinggi. Hasil ini mendukung $\left(\mathrm{H}_{1}\right)$ yang menyatakan bahwa idealisme yang berpengaruh positif pada persepsi mahasiswa akuntansi atas perilaku etis akuntan. Seseorang yang memiliki sikap idealisme yang tinggi mempunyai prinsip bahwa merugikan individu lain adalah hal yang selalu dapat atau harus dihindari dan mereka tidak akan melakukan tindakan yang mengarah pada tindakan yang berkonsekuensi negatif. Oleh karena itu, semakin tinggi idealisme maka kemungkinan untuk melakukan perilaku tidak etis semakin rendah. Jadi, mahasiswa dengan idealisme tinggi akan berpersepsi lebih etis atas perilaku etis yang melibatkan akuntan.

Hasil penelitian ini didukung oleh Milyawati, dkk (2017) yang menunjukkan bahwa tingkat idealisme berpengaruh pada opini mahasiswa 
terhadap perilaku etis akuntan. Hasil penelitian ini juga didukung Setiawan (2013) dan Putra (2015) menunjukkan bahwa idealisme berpengaruh signifikan positif terhadap perilaku etis. Ini berarti bahwa hubungan idealisme searah dengan perilaku etis akuntan. Dapat diartikan semakin tinggi tingkat idealisme yang dimiliki seseorang maka akan meningkatkan perilaku etisnya dalam melaksanakan tanggungjawab sebagai profesional akuntansi.

Hasil analisis menunjukan koefisien regresi relativisme memiliki tanda negatif. Hal ini menunjukkan bahwa semakin tinggi sifat relativisme mahasiswa akuntansi menyebabkan persepsi mahasiswa akuntansi atas perilaku etis akuntan semakin rendah. Hasil ini mendukung $\left(\mathrm{H}_{2}\right)$ yang menyatakan bahwa relativisme yang berpengaruh negative pada persepsi mahasiswa akuntansi atas perilaku etis akuntan. Seseorang yang relativisme tinggi justru tidak mengindahkan prinsipprinsip yang ada dan lebih melihat keadaan sekitar sebelum bertindak atau merespon kejadian yang melanggar etika. Oleh karena itu, semakin tinggi relativisme maka kemungkinan untuk melakukan perilaku etis semakin rendah. Jadi, mahasiswa dengan relativisme tinggi akan berpersepsi lebih tidak etis atas perilaku etis yang melibatkan akuntan.

Hasil penelitian ini di dukung oleh Nurfarida (2011), Setiawan (2013), dan Putra (2015) menunjukkan bahwa relativisme mempunyai pengaruh negatif terhadap perilaku etis akuntan. Ini berarti bahwa hubungan relativisme berlawanan arah dengan perilaku etis akuntan. Dapat diartikan semakin tinggi tingkat relativisme seseorang maka akan menurunkan perilaku etis dalam melaksanakan tanggung jawab sebagai profesional akuntansi. 
Hasil analisis menunjukan koefisien regresi etika memiliki tanda positif. Hal ini menunjukkan bahwa semakin tinggi etika mahasiswa akuntansi menyebabkan persepsi mahasiswa akuntansi atas perilaku etis akuntan semakin tinggi. Hasil ini mendukung $\left(\mathrm{H}_{3}\right)$ yang menyatakan bahwa etika yang berpengaruh positif pada persepsi mahasiswa akuntansi atas perilaku etis akuntan. Seseorang yang memiliki etika tinggi akan lebih bersikap bijaksana dan memberikan tanggapan baik terhadap perilaku etis dibandingan dengan mahasiswa yang memiliki etika rendah akan memberikan tanggapan bahwa bersikap melanggar etika adalah suatu sikap yang tidak merugikan.

Oleh karena itu, semakin tinggi etika maka kemungkinan untuk melakukan perilaku tidak etis semakin rendah. Jadi, mahasiswa dengan etika tinggi akan berpersepsi lebih etis atas perilaku etis yang melibatkan akuntan. Hasil penelitian ini didukung oleh penelitian Dewi (2010) dan Pamela (2014) yang menunjukkan bahwa etika berpengaruh signifikan positif terhadap perilaku etis akuntan.

Penelitian yang dilakukan diharapkan dapat memberikan kontribusi mengenai pengaruh idealisme, relativisme dan etika pada persepsi mahasiswa akuntansi atas perilaku etis akuntan. Hasil uji dalam penelitian ini ditemukan bahwa idealisme dan etika berbanding lurus dengan persepsi mahasiswa atas perilaku etis akuntan, sedangkan relativisme berbanding terbalik dengan persepsi mahasiswa atas perilaku etis akuntan. Teori moral kognitif menjelaskan bahwa seseorang harus melewati sebuah urutan sebagai tahapan perkembangan moral, dimana semakin tinggi tahapan seseorang, maka semakin mengerti dan dapat 
membedakan perilaku etis dan tidak etis. Perkembangan moral bergantung pada perkembangan intelektual seseorang.

Semakin tinggi tahapan perkembangan moral seseorang juga diharapkan mampu meningkatkan etika mereka sehingga mereka mampu menilai dan memberikan tanggapan jika di lingkungannya terjadi perilaku yang menyimpang atau tidak etis dimana biasanya seseorang pada tahapan perkembangan moral yang paling tinggi akan cenderung bersikap sesuai dengan prinsip-prinsip etika yang ada. Berbeda dengan seseorang yang relative yang berpandangan bahwa tidak ada standar etis yang secara absolute benar dan mengikuti standar moral yang berlaku dalam masyarakat dimanapun seseorang tersebut berada.

Penelitian ini diharapkan agar mahasiswa akuntansi lebih meningkatkan perilaku etisnya. Berdasarkan kasus-kasus pelanggaran etika yang melibatkan akuntan, mahasiswa akuntansi yang akan menjadi calon akuntan akan belajar memahami masalah-masalah etika, karena bidang profesi akuntansi mempunyai kepercayaan penuh oleh masyarakat yang nantinya tidak akan terjadi krisis kepercayaan.

Sejak dini mahasiswa diharapkan dapat bersikap ideal atau memegang teguh prinsip etika nya di dalam menghadapi suatu masalah di lingkungannya, dan lebih bijaksana dalam mengambil keputusan atau bertindak jika di hadapkan dengan situasi yang melanggar etika sehingga ke depannya mampu menghasilkan lulusan yang berkompeten dan siap bekerja, serta meminimalisir berbagai kasus kecurangan yang melibatkan profesi akuntan. 


\section{SIMPULAN}

Berdasarkan pembahasan hasil penelitian dari bab sebelumnya terhadap variabel variabel bebas yang mempengaruhi Perilaku mahasiswa atas perilaku etis akuntan yang diukur dengan variabel relativisme, idealisme dan etika dapat disimpulkan sebagai berikut: 1) Idealisme berpengaruh positif dan signifikan terhadap Persepsi mahasiswa atas perilaku etis akuntan. Hal ini berarti bahwa mahasiswa dengan tingkat idealisme yang tinggi maka akan berpersepsi lebih etis atas perilaku etis yang melibatkan akuntan. 2) Relativisme berpengaruh negatif dan signifikan terhadap Persepsi mahasiswa atas perilaku etis akuntan. Hal ini berarti bahwa semakin tinggi relativisme mahasiswa tersebut, maka akan semakin rendah persepsi mahasiswa akuntansi atas perilaku etis yang melibatkan akuntan. 3) Etika berpengaruh positif dan signifikan secara statistik terhadap Persepsi mahasiswa atas perilaku etis akuntan. Hal ini berarti bahwa semakin tinggi etika mahasiswa tersebut, maka akan semakin tinggi persepsi mahasiswa akuntansi atas perilaku etis yang melibatkan akuntan.

Berdasarkan kesimpulan diatas, maka dapat disampaikan juga beberapa saran, yakni sebagai berikut. 1) Mahasiswa sebagai calon akuntan dan auditor yang profesional, harus menghindari sifat dan prilaku yang tidak etis karena seorang akuntan dan auditor merupakan tenaga profesional yang mengandalkan kepercayaan pada masyarakat. 2) Bagi peneliti selanjutnya disarankan untuk memperluas ruang lingkup penelitian dengan mengambil sampel mahasiswa akuntansi dari perguruan tinggi negeri dan swasta lainnya. 3) Bagi peneliti selanjutnya disarankan untuk mengembangkan penelitian ini dengan meneliti 
faktor-faktor lain seperti informasi, pengalaman yang memiliki pengaruh terhadap persepsi mahasiswa akuntansi atas perilaku etis akuntan.

\section{REFERENSI}

Akbar, M. T. (2013). Analisis Perbedaan Penerapan Etika Profesi Akuntan Dipandang dari segi Gender dan Tingkat Pendidikan (studi empiris pada mahasisa akuntansi di kota Padang). http://ejournal.unp.ac.id. Diakses tanggal 19 Agustus 2017.

Arens, A., J. Randal., E. Mark., S. Beasley., dan A. J. Amir. (2012). Jasa Auditdan Assurance: Pendekatan Terpadu (Adaptasi Indonesia). Jilid I. Penerbit Salemba Empat: Jakarta.

Arfan, I. L. (2011). Akuntansi Keperilakuan. Jakarta: Salemba Empat.

Arikunto, S. (2010). Prosedur Penelitian Suatu Pendekatan Praktik. Jakarta: Rinaka Cipta.

Cherington, D. J. (1994). Organizational Behaviour: The Management of Individual and Organizational Performance. Boston. Allyand Balon.

Chung, J. and G. S. Monroe. (2003). Exploring Social Desirability Bias. Journal of Business Ethics, 44(4), 291-302.

Comunale, C., S. Thomas., and S. Gara. (2006). Profesional Ethical Crises; A Case Study of Accounting Majors. Managerial Auditing Journal, 21(6), 636-656.

Damayanthi, P. D. A. (2016). Pengaruh Idealisme, Relativisme, Pengetahuan, Gender dan Umur pada Perilaku Tidak Etis Akuntan. E-jurnal Akuntansi Universitas Udayana, 15(1), 1-16.

Duska, R., B. S. Duska and J. A. Ragatz. (2011). Accounting Ethics. United Kingdom: Wiley Blacwell.

Dzakirin, M. K. (2013). Orientasi Idealisme, Relativisme, Tingkat Pengetahuan, dan Gender: Pengaruhnya pada Persepsi Mahasiswa tentang Krisis Etika Akuntan Profesional. Jurnal Ilmiah Orasi Bisnis, 2(1).

Falah, S. (2006). Pengaruh Budaya Etis Organisasi dan Orientasi Etika Terhadap Sensitivitas Etika. SNA $X$ Makasar.

Ferdinandus, R. P. (2016). Pengaruh Sensitivitas Etika terhadap Persepsi Mahasiswa atas Perilaku Etis Akuntan (Studi Kasus pada Mahasiswa Akuntansi Universitas Negeri Yogyakarta). Jurnal Profita. 
Fitria, M. (2015). Pengaruh Orientasi Idealisme, Relativisme, Tingkat Pengetahuan Akuntansi, dan Gender Terhadap Persepsi Mahasiswa Akuntansi Tentang Krisis Etika Akuntan Profesional (Studi Empiris Mahasiswa Akuntansi Perguruan Tinggi di Kota Padang). Skripsi. Fakultas Ekonomi Negeri Padang.

Forsyth, D. (1980). A Taxonomy of Ethical Ideologies. Journal of Personality and Social Psychology, 39, 175-184.

. (1992). Judging the Morality of Business Practices: the Influence of Personal Moral Philosophies. Journal of Business Etchics, 11, 416-470.

Forsyth, D and J. Nye. (1990). Personal Moral Philosophies and Moral Choice. Journal of Research in Personality, 24, 398-414.

Fraenkel, J. R. (1977). How to teach about values: an analytic approach. New Jersey: Prentice-Hall, Inc.

Ghozali, I. (2016). Aplikasi Analisis Multivariate dengan Program SPSS. Semarang: Universitas Diponegoro.

Gray, R., J. Bebbington., and K. McPhail. (1994). Teaching ethics in accounting and the ethics of accounting teaching: Educating for immorality and a possible case for social and environmental accounting education, Accounting Education, 3(1), 51-75.

Griffin, R. And G. Moorhead. (2014). Organizational Behavior: Managing People and Organizations: Ricky W. Griffin, Gregory Moorhead, Cengage Learning.

Herwinda, N. D. (2010). Persepsi Mahasiswa atas Perilaku Tidak Etis Akuntan. Skripsi. Universitas Diponegoro.

Hunt, S. D. and S. Vitell. (1986). A General Theory of Marketing Ethics. Journal of Macromarketing, 5-16.

https://www.newsliputan6.com/ diakses tanggal 1, September 2017.

Kamus Besar Bahasa Indonesia. Edisi Keempat. (2008). Jakarta: Balai Pustaka.

Kohlberg, L. (1976). Moral stages and moralization: The cognitive-developmental approach, Moral development and behavior: Theory. research and social issues, 31-53.

Larkin, J. M. (2000). The Ability of Internal Auditors to Identify Ethical Dillemas. Journal of Business Ethics, 23, 401-409. 
Ludigdo, U. (1999). Pengaruh Jenis Kelamin terhadap Etika Bisnis: Studi terhadap Persepsi Akuntan dan Mahasiswa Akuntansi. Simposium Nasional Akuntansi (SNA) II, Malang.

Ludigdo, U. dan M. Machfoeds. (1999). Persepsi Akuntan dan Mahasiswa terhadap Etika Bisnis. Jurnal Riset Akuntansi Indonesia, 2(1).

Maryani, T. dan U. Ludigdo. (2001). Survey atas Faktor-faktor yang Mempengaruhi Sikap dan Perilaku Etis Akuntan. Jurnal TEMA, 2(1), 4962.

Marwanto. (2007). Pengaruh Pemikiran Moral, Tingkat Idealisme, Tingkat Relativisme dan Locus of Control terhadap Sensitivitas, Pertimbangan, Motivasi dan Karakter Mahasiswa Akuntansi. Tesis. Universitas Diponegoro.

Milyawati, A. U. dan D. Darmawan. (2017). Pengaruh Idealisme, Relativisme, Love of Money, Gender dan Tingkat Pengetahuan Akuntansi terhadap Persepsi Mahasiswa Akuntansi atas Perilaku Etis Akuntan. Jurnal Universitas Maritim Raja Ali Haji.

Morgan, R. B. (1993). Self and Co-worker Perceptions of Ethics and Their Relationship to Leadership and Salary. Academy of Management Journal, $36,200-214$.

Munawir. (2005). Auditing Modern. Edisi ke 5 Yogyakarta: BPFE.

Neisser, U. (1976). Cognition and reality: principles and implications of cognitive psychology. New York: Freeman, 7(3), 500-507.

Nugroho, B. (2008). Faktor-Faktor yang Mempengaruhi Penilaian Mahasiswa Akuntansi Atas Tindakan Auditor dan Coorporate Manager dalan Skandal Keuangan serta Tingkat Ketertarikan Belajar dan Berkarir di Bidang Akuntansi (Studi Empiris pada Mahasiswa Akuntansi Universitas Diponegoro). Tesis. Universitas Diponegoro.

Nurfarida, L. (2011). Pengaruh Budaya Etis Organisasi dan Orientasi Etika terhadap Komitmen Organisasi dan Sensitivitas Etika Auditor. Skripsi, UIN Syarif Hidayatullah.

O'Higgins, E. and B. Kelleher. (2005). Comparative perspectives on the ethical orientations of human resources, marketing and finance functional managers. Journal of Business Ethics, 275-288.

O'leary, C. dan D. Cotter. (2000). The Ethics of Final Year Accountancy Students: an International Comparison. Managerial Auditing Journal. 
O'leary, C. dan G. Pangemanan. (2007). The Effect of Groupwork on Ethical Students Decision-Making of Accountancy. Journal of Business Ethics.

Pamela, A. (2014). Pengaruh Pemahaman Kode Etik Profesi Akuntan Terhadap Perilaku Etis Pada Mahasiswa Akuntansi Universitas Negeri Yogyakarta, Journal of Moral Education.

Putra, A. A. (2015). Pengaruh Orientasi Etika, Locus Of Control dan Budaya Organisasi terhadap Perilaku Etis Akuntan. Jurnal Riset Akuntansi.

Revita M. (2014). Pengaruh Orientasi Etis, Gender, Dan Pengetahuan Etika Terhadap Persepsi Mahasiswa Akuntansi Atas Perilaku Tidak Etis Akuntan. Jurnal. Universitas Negeri Yogyakarta.

Sari, L. P. (2012). Pengaruh Muatan Etika dalam Pendidikan Akuntansi terhadap Persepsi Etika Mahasiswa. Jurnal Akuntansi Multiparadigma, 3(3), 380392.

Setiawan, A. S. (2013). Pengaruh Budaya Etis, Orientasi Etis terhadap Perilaku Etis. Skripsi. STIE Musi Palembang.

Sihwahjoeni dan M. Godono. (2000). Persepsi Akuntan terhadap Kode Etik Akuntan. Jurnal Riset Akuntansi Indonesia, 3(2), 168-184.

Smith, B. (2009). Ethical Ideology and Cultural Orientation: Understanding The Individualized Ethical Inclinations Of Marketing Students. American Journal of Business Education, 2(8).

Sugiantari, N. K. (2016). Pengaruh Idealisme, Relativisme dan Love of Money pada Persepsi Mahasiswa Akuntansi Tentang Krisis Etika Akuntan. EJurnal Akuntansi. Universitas Udayana.

Sugiyono. (2017). Metode Penelitian (Kuantitatif, Kualitatif, dan R\&D). Bandung: Alfabeta.

Sukrisno,A. dan I. C. Ardana. (2009). Etika Bisnis dan Profesi: Tantangan Membangun Manusia Seutuhnya. Jakarta: Salemba Empat.

Syaikhul, F. (2006). Pengaruh Budaya Etis Organisasi dan Orientasi Etika terhadap Sensitivitas Etika. Tesis. Universitas Diponegoro.

Umar, H. (2004). Metode Penelitian untuk Skripsi dan Tesis Bisnis. Cetakan ke-6. Jakarta: PT Raja Grafindo Persada.

Utami, N. I. Pengaruh Locus of Control, Komitmen Profesional dan Pengalaman Audit terhadap Perilaku Akuntan Publik dalam Konflik Audit dengan Kesadaran Etis sebagai Variabel Pemoderasi. Jurnal Akuntansi dan Keuangan Indonesia, 4(2), 192-2010. 
Widyaningrum, A. (2014). Determinan Persepsi Etika Mahasiswa Akuntansi dengan Love of Money sebagai Variabel Intervening. Jurnal Fakultas Ekonomi dan Bisnis Universitas Brawijaya, 1-28.

Ziegenfuss, D. E. and O. B. Martinson. (2002). The IMA Code of Ethics and IMA Members' Ethical Perception and Judgment. Managerial Auditing Journal, 17, 165-173.

Zulfahmi. (2005). Analisa Faktor-Faktor Yang Mempengaruhi Sikap dan perilaku Etis Akuntan Publik di Kota Banda Aceh. Skripsi. Universitas Syiah Kuala. 